\title{
BASIC EXCHANGEABLE CATIONS IN FINNISH MINERAL SOILS
}

\author{
Armi Kaila \\ University of Helsinki, Department of Agricultural Chemistry
}

Received May 29, 1972

\begin{abstract}
The content of exchangeable $\mathrm{Ca}, \mathrm{Mg}, \mathrm{K}$ and $\mathrm{Na}$ replaced by neutral ammonium acetate was determined in 470 samples of mineral soils from various parts of Finland, except from Lapland.

The amount of all these cations tended to increase with an increase in the clay content, but variation within each textural class was large, and the ranges usually overlapped those of the other classes.

The higher acidity of virgin surface soils was connected with a lower average degree of saturation by $\mathrm{Ca}$ as compared with the corresponding textural classes of cultivated soils. No significant difference in the respective contents of other cations was detected.

The samples of various textural groups from deeper layers were usually poorer in exchangeable $\mathrm{Ca}$ and $\mathrm{K}$ than the corresponding groups of plough layer. The mean content of exchangeable $\mathrm{Mg}$ was equal or even higher in the samples from deeper layers than in the samples from plough layer, except in the group of sand soils.

The percentage of $\mathrm{Mg}$ of the effective CEC increased, as an average, from 9 in the sand and fine sand soils of plough layer to 30 in the heavy clay soils; in the heavy clay soils from deeper layers its mean value was $38 \pm 4 \%$.

In the samples of plough layer, the mean ratio of $\mathrm{Ca}$ to $\mathrm{Mg}$ in sand and fine sand soils was about 9 , in silt and loam soils about 6 , in the coarser clay soils about 4 , and in heavy clay about 2 .
\end{abstract}

Chemical and physical properties of a soil may largely depend on the quality and quantity of exchangeable cations in it. The degree of saturation by basic cations is of particular importance, but also the proportions of various basic cations and their amounts in soil exert marked effect on plant nutrition and, especially, on properties of clay soils.

Information about basic exchangeable cations in Finnish soils obtained by modern analytical methods is not particularly abundant. HeINONEN (1956) has reported results of exchangeable $\mathrm{Ca}, \mathrm{Mg}$, and $\mathrm{K}$ in the plough layer of about 50 mineral or organic soils. MartTila (1965) published data of a material consisting of 100 samples from surface and deeper layers of both cultivated and virgin soils, and MÄKITIE and VIRRI (1965) studied 10 clay soil profiles of Southern Finland. Their results do not differ from the 
general rule that the content of exchangeable $\mathrm{Ca}$ is usually higher than that of $\mathrm{Mg}$, and both of them markedly higher than those of $\mathrm{K}$ and $\mathrm{Na}$. Clay soils, especially their deeper layers appeared to be fairly rich in $\mathrm{Mg}$.

In the present paper the content of basic exchangeable cations in Finnish soils of different textural classes is studied on the basis of a larger material. Attention is also paid to differences between cultivated and virgin soils on the one hand, and between surface soils and deeper layers on the other hand. In order to get a more realistic idea about the conditions in the field, the degree of saturation by the various cations is calculated using the effective cation exchange capacity instead of some potential value determined at a higher $\mathrm{pH}$ than those existing in our more or less acid soils:

\section{Material and methods}

The material consists of 470 soil samples collected from various parts of Finland, except from Lapland. The surface samples were taken down to about $20 \mathrm{~cm}$, the samples of the deeper layers mainly from depths between 20 and $70 \mathrm{~cm}$.

The samples were air-dried and ground, and the particles larger than $2 \mathrm{~mm}$ were separated by sieving. On the basis of the particle size composition of mineral matter, the samples were grouped according to the classification used in Finland. Soils containing the fraction $<2 \mu \mathrm{m}$ more than $60 \%$ are listed as heavy clays. Of the other clay soils with 30 to $60 \%$ clay, the silt clay soils contain 20 to $70 \%$ silt $(2-20 \mu \mathrm{m})$ and less than $20 \%$ fine sand $(20-200 \mu \mathrm{m})$, clay loam contains both these fractions 20 to $50 \%$, and the sandy clay soils less than $20 \%$ silt and 20 to $70 \%$ fine sand. Since there were only 11 samples of sandy clay soils in this material, they were pooled with the clay loam soils. The non-clay soils with less than $30 \%$ clay are silt soils with more than $50 \%$ silt, fine sand soils with more than $50 \%$ fine sand, or loam soils with 20 to $50 \%$ of both these fractions. The sand soils are mainly composed of the fraction 0.2 to $2 \mathrm{~mm}$. The moraine soils got into the groups of sand or fine sand soils.

Soil $\mathrm{pH}$ was measured in 1 to 2.5 suspension in $0.01 \mathrm{M} \mathrm{CaCl}_{2}$, organic $\mathrm{C}$ was determined by wet combustion and iodometric titration.

The basic exchangeable cations were extracted by washing with centrifuge $10 \mathrm{~g}$-samples of soil with five $50 \mathrm{ml}$-portions of neutral ammonium acetate. $\mathrm{Ca}$ and $\mathrm{Mg}$ were measured by a Perkin Elmer atomic absorption spectrophotometer 290, and $\mathrm{K}$ and $\mathrm{Na}$ with an EEL flame photometer.

The effective CEC was calculated as the sum of the basic exchangeable cations and exchange acidity displaced by successive extractions with unbuffered $\mathrm{N} \mathrm{KCl}$.

The soil samples are characterized by data in Table 1. Because no statistically significant differences could be detected in this work between the subsurface samples of the same textural classes in cultivated and virgin soils, this part of material is treated without attention to its origin. There were 74 samples of clay soils and 52 samples of non-clay soils from the deeper layers of cultivated land, 39 samples of clay soils and 61 samples of non-clay soils from virgin land.

It is of interest to note that the average clay content is equal in the sand and fine sand soils, in the loam and silt soils, and in the two groups of coarser clay soils, respectively. Corresponding equality is also reflected by the mean values of effective CEC. The heavy clay soils have a markedly higher mean CEC than the other clay soils.

\section{Results}

The mean contents of basic exchangeable cations in the various soil groups are listed 
Table 1. Soil samples.

\begin{tabular}{|c|c|c|c|c|c|}
\hline & $\begin{array}{l}\text { Number } \\
\text { of } \\
\text { samples }\end{array}$ & $\mathrm{pH}^{*}$ & Org. C \%* & Clay \%* & $\begin{array}{c}\text { Effective } \\
\text { CEC } \\
\text { me } / 100 \mathrm{~g}^{*}\end{array}$ \\
\hline \multicolumn{6}{|l|}{ Surface samples } \\
\hline Sand & 20 & $5.4 \pm 0.2$ & $3.3 \pm 0.7$ & $11 \pm 3$ & $9.8 \pm 1.8$ \\
\hline Fine sand & 29 & $5.2 \pm 0.2$ & $2.9 \pm 0.4$ & $10 \pm 2$ & $9.1 \pm 1.6$ \\
\hline Loam & 58 & $5.2 \pm 0.1$ & $2.7 \pm 0.2$ & $21 \pm 1$ & $10.2 \pm 0.7$ \\
\hline Silt & 16 & $5.3 \pm 0.2$ & $3.4 \pm 0.7$ & $20 \pm 3$ & $13.0 \pm 2.1$ \\
\hline Clay loam & 35 & $5.2 \pm 0.2$ & $4.2 \pm 0.5$ & $39 \pm 2$ & $16.6 \pm 1.7$ \\
\hline Silty clay & 36 & $5.2 \pm 0.1$ & $4.0 \pm 0.4$ & $42 \pm 3$ & $15.7 \pm 1.8$ \\
\hline \multicolumn{3}{|l|}{ virgin soils } & $4.6 \pm 1.4$ & $71 \pm 6$ & $22.6 \pm 3.3$ \\
\hline Sand and fine sand & 26 & $4.4 \pm 0.2$ & $4.8 \pm 0.9$ & $11 \pm 2$ & $9.3 \pm 1.2$ \\
\hline Loam and silt & 12 & $4.5 \pm 0.2$ & $4.0 \pm 1.4$ & $20 \pm 3$ & $9.9 \pm 2.2$ \\
\hline Clay & 9 & $4.5 \pm 0.5$ & $3.4 \pm 1.8$ & $59 \pm 12$ & $18.6 \pm 0.3$ \\
\hline \multicolumn{6}{|l|}{ Deeper layers } \\
\hline Sand & 26 & $4.6 \pm 0.1$ & $0.9 \pm 0.2$ & $8 \pm 2$ & $2.7 \pm 0.4$ \\
\hline Fine sand & 37 & $5.1 \pm 0.2$ & $0.7 \pm 0.2$ & $6 \pm 2$ & $3.2 \pm 0.9$ \\
\hline Loam & 25 & $5.1 \pm 0.2$ & $0.9 \pm 0.3$ & $20 \pm 3$ & $7.0 \pm 0.1$ \\
\hline Silt & 25 & $5.2 \pm 0.3$ & $0.9 \pm 0.4$ & $20 \pm 3$ & $7.1 \pm 0.1$ \\
\hline Clay loam & 19 & $5.1 \pm 0.5$ & $1.0 \pm 0.4$ & $42 \pm 4$ & $14.5 \pm 2.5$ \\
\hline Silty clay & 40 & $5.4 \pm 0.2$ & $0.8 \pm 0.2$ & $44 \pm 3$ & $13.7 \pm 1.6$ \\
\hline Heavy clay & 44 & $5.7 \pm 0.2$ & $0.9 \pm 0.3$ & $76 \pm 3$ & $25.5 \pm 2.3$ \\
\hline
\end{tabular}

${ }^{*}$ Means with the confidence limits at the 95 per cent level.

in Table 2. The increase in the effective CEC from sand to heavy clay soils appears to be due to increases in the amounts of all four cations.

The content of exchangeable Ca ranged in these samples from $0.1 \mathrm{me} / 100 \mathrm{~g}$ in the $\mathrm{A}_{2}$-horizon of a podsol soil to more than $20 \mathrm{me} / 100 \mathrm{~g}$ in some cultivated clay soils. There seems to be a higher average content of $\mathrm{Ca}$ in the plough layers of the cultivated soils than in the corresponding groups from deeper layers or from the surface soils of virgin lands. Only the 44 samples of heavy clay from the deeper layers have a mean content of exchangeable $\mathrm{Ca}$ as high as the 13 samples from plough layer.

The mean content of exchangeable $\mathrm{Mg}$ seems to increase from sand to heavy clay soils even more markedly than that of exchangeable Ca. The lowest values, less than $0.1 \mathrm{me} / 100 \mathrm{~g}$, were found in deeper layers of sand soils, and the highest, about $20 \mathrm{me} / 100$ $\mathrm{g}$, in the deeper layers of heavy clay soils. Contrary to the occurrence of exchangeable $\mathrm{Ca}$, the content of exchangeable $\mathrm{Mg}$ does not seem to be higher in the plough layer than in the deeper layers; in the clay soils even higher average content is found in the subsurface samples. No significant difference exists between the corresponding kinds of virgin and cultivated soils. 
Table 2. Basic exchangeable cations, me/100 $\mathrm{g}$ of soil.

\begin{tabular}{|c|c|c|c|c|}
\hline & $\mathrm{Ca}^{*}$ & $\mathrm{Mg}^{*}$ & $\mathrm{~K}^{*}$ & $\mathrm{Na}^{*}$ \\
\hline \multicolumn{5}{|l|}{ Surface samples } \\
\hline \multicolumn{5}{|l|}{ cultivated soils } \\
\hline Sand & $7.7 \pm 1.5$ & $0.9 \pm 0.3$ & $0.44 \pm 0.14$ & $0.16 \pm 0.06$ \\
\hline Fine sand & $7.2 \pm 1.6$ & $0.8 \pm 0.2$ & $0.35 \pm 0.08$ & $0.15 \pm 0.06$ \\
\hline Loam & $7.8 \pm 0.7$ & $1.2 \pm 0.2$ & $0.32 \pm 0.05$ & $0.16 \pm 0.06$ \\
\hline Silt & $10.0 \pm 2.0$ & $1.6 \pm 0.5$ & $0.52 \pm 0.29$ & $0.21 \pm 0.10$ \\
\hline Clay loam & $11.6 \pm 1.2$ & $2.8 \pm 0.7$ & $0.67 \pm 0.14$ & $0.24 \pm 0.03$ \\
\hline Silty clay & $11.3 \pm 1.4$ & $2.6 \pm 0.5$ & $0.62 \pm 0.09$ & $0.24 \pm 0.02$ \\
\hline Heavy clay & $14.0 \pm 2.7$ & $6.7 \pm 1.1$ & $0.81 \pm 0.19$ & $0.33 \pm 0.09$ \\
\hline \multicolumn{5}{|l|}{ virgin soils } \\
\hline Sand and fine sand & $5.3 \pm 1.2$ & $1.2 \pm 0.2$ & $0.30 \pm 0.10$ & $0.15 \pm 0.03$ \\
\hline Loam and silt & $4.9 \pm 2.3$ & $1.5 \pm 0.5$ & $0.41 \pm 0.11$ & $0.17 \pm 0.06$ \\
\hline Clay & $8.7 \pm 3.0$ & $4.7 \pm 2.9$ & $0.89 \pm 0.66$ & $0.34 \pm 0.15$ \\
\hline \multicolumn{5}{|l|}{ Deeper layers } \\
\hline Sand & $1.1 \pm 0.3$ & $0.3 \pm 0.1$ & $0.09 \pm 0.03$ & $0.06 \pm 0.01$ \\
\hline Fine sand & $1.7 \pm 0.8$ & $0.5 \pm 0.4$ & $0.14 \pm 0.04$ & $0.14 \pm 0.06$ \\
\hline Loam & $3.9 \pm 1.2$ & $1.7 \pm 0.5$ & $0.26 \pm 0.05$ & $0.17 \pm 0.03$ \\
\hline Silt & $4.0 \pm 0.6$ & $1.9 \pm 0.4$ & $0.19 \pm 0.05$ & $0.18 \pm 0.03$ \\
\hline Clay loam & $7.7 \pm 2.9$ & $3.6 \pm 1.1$ & $0.38 \pm 0.09$ & $0.42 \pm 0.15$ \\
\hline Silty clay & $7.2 \pm 1.1$ & $4.5 \pm 0.9$ & $0.40 \pm 0.08$ & $0.31 \pm 0.06$ \\
\hline Heavy clay & $13.2 \pm 1.3$ & $10.1 \pm 1.6$ & $0.73 \pm 0.07$ & $0.56 \pm 0.07$ \\
\hline
\end{tabular}

*Means with the confidence limits at the 95 per cent level.

The average ratio of exchangeable $\mathrm{Ca}$ to $\mathrm{Mg}$ in the plough layers is in sand and fine sand soils about 9 , in silt and loam soils about 6 , in clay loam and silt clay about 4 and in heavy clay soils about 2 . In the deeper layers the corresponding ratios are about $3.5,2,2$, and less than 1.5 , respectively. The surface samples of virgin soils stand halfway between these.

The surface layers seem to be markedly richer in exchangeable $\mathrm{K}$ than the deeper layers. The minimum content, $0.01 \mathrm{me} / 100 \mathrm{~g}$, was found in the deeper layers of virgin fine sand soil, and the highest contents, $1.9 \mathrm{me} / 100 \mathrm{~g}$ in the plough layer of a silt and clay loam soil. The content of exchangeable $\mathrm{K}$ seems to increase with the increase in the content of clay, though less markedly than does $\mathrm{Mg}$.

In the mineral soils there is roughly twenty times as much exchangeable $\mathrm{Ca}$ as exchangeable $\mathrm{K}$. The average ratio of exchangeable $\mathrm{Mg}$ to $\mathrm{K}$ varies from about 2 in the plough layer of sand and fine sand soils to more than 8 in the heavy clay soils. In the virgin soils and in the deeper layers the ratio tends to be higher.

In the surface layers of the mineral soils the mean content of exchangeable $\mathrm{Na}$ in the respective textural classes is distinctly lower than that of exchangeable $\mathrm{K}$, but in the 
Table 3. Basic exchangeable cations as a per cent of effective cation exchange capacity.

\begin{tabular}{|c|c|c|c|c|}
\hline & $\mathrm{Ca}^{*}$ & $\mathrm{Mg}^{*}$ & $\mathrm{~K}^{*}$ & $\mathrm{Na}^{*}$ \\
\hline \multicolumn{5}{|l|}{ Surface samples } \\
\hline \multicolumn{5}{|l|}{ cultivated soils } \\
\hline Sand & $78 \pm 2$ & $9 \pm 2$ & $4 \pm 1$ & $2 \pm 0.5$ \\
\hline Fine sand & $76 \pm 4$ & $9 \pm 2$ & $4 \pm 2$ & $2 \pm 1$ \\
\hline Loam & $76 \pm 2$ & $12 \pm 1$ & $3 \pm 0.5$ & $1 \pm 0.2$ \\
\hline Silt & $75 \pm 6$ & $12 \pm 3$ & $5 \pm 2.5$ & $2 \pm 0.5$ \\
\hline Clay loam & $70 \pm 3$ & $11 \pm 3$ & $4 \pm 1$ & $1 \pm 0.2$ \\
\hline Silty clay & $71 \pm 3$ & $15 \pm 2$ & $5 \pm 1$ & $2 \pm 0.2$ \\
\hline Heavy clay & $61 \pm 5$ & $30 \pm 4$ & $4 \pm 1$ & $1 \pm 0.3$ \\
\hline \multicolumn{5}{|l|}{ virgin soils } \\
\hline Sand and fine sand & $55 \pm 8$ & $13 \pm 2$ & $3 \pm 1$ & $2 \pm 0.3$ \\
\hline Loam and silt & $45 \pm 15$ & $13 \pm 3$ & $4 \pm 1$ & $2 \pm 0.5$ \\
\hline Clay & $47 \pm 16$ & $24 \pm 11$ & $5 \pm 1$ & $2 \pm 1$ \\
\hline \multicolumn{5}{|l|}{ Deeper layers } \\
\hline Sand & $41 \pm 5$ & $10 \pm 2$ & $4 \pm 0.5$ & $2 \pm 0.4$ \\
\hline Fine sand & $42 \pm 7$ & $13 \pm 3$ & $5 \pm 1.5$ & $6 \pm 3$ \\
\hline Loam & $50 \pm 7$ & $21 \pm 4$ & $4 \pm 1$ & $3 \pm 0.5$ \\
\hline Silt & $54 \pm 5$ & $25 \pm 4$ & $3 \pm 1.5$ & $3 \pm 0.5$ \\
\hline Clay loam & $50 \pm 11$ & $15 \pm 7$ & $3 \pm 0.5$ & $3 \pm 1$ \\
\hline Silty clay & $52 \pm 5$ & $31 \pm 4$ & $3 \pm 0.5$ & $2 \pm 0.4$ \\
\hline Heavy clay & $52 \pm 4$ & $38 \pm 4$ & $3 \pm 0.5$ & $2 \pm 0.3$ \\
\hline
\end{tabular}

${ }^{*}$ Means with the confidence limits at the 95 per cent level.

deeper layers the difference is smaller or there is no difference. In some exceptional cases the content of exchangeable $\mathrm{Na}$ is even markedly higher than that of $\mathrm{K}$.

The variation in the content of exchangeable $\mathrm{Ca}, \mathrm{Mg}, \mathrm{K}$ and $\mathrm{Na}$ is large in all textural classes, and individual values of one group are overlapping the range of other ones. This is, of course, true also in the variation of the degree of saturation of the exchange capacity by the basic cations. Yet, the average saturation percentages may significantly differ at least between more distant textural classes, as shown by the data in Table 3.

The average degree of saturation by exchangeable $\mathrm{Ca}$ is distinctly lower in the plough layer samples of heavy clay soils than in those of a coarser texture. It varies from about $80 \%$ in sand soils to about $60 \%$ in the heavy clay samples, while the degree of saturation with $\mathrm{Mg}$ increases from an average of about $10 \%$ to $30 \%$. Together these two basic cations saturate, on an average, 80 to $90 \%$ of the effective CEC of these cultivated soils.

In the virgin samples and in the soils from deeper layers the degree of saturation by $\mathrm{Mg}$ is of the same order as in the corresponding textural classes of plough layer samples, 
but the mean proportion of $\mathrm{Ca}$ is distinctly lower in the former groups. In all the samples of the plough layer at least $50 \%$ of the exchangeable cations are $\mathrm{Ca}$, but in the virgin soils the minimum may be about $10 \%$ in particularly acid soils.

The proportions of exchangeable $\mathrm{K}$ and $\mathrm{Na}$ do not show any distinct tendency to be connected with the textural class or sampling depth. Cultivation does not seem to have any significant effect on them.

\section{Discussion}

The contents of exchangeable $\mathrm{Ca}, \mathrm{Mg}, \mathrm{K}$ and $\mathrm{Na}$, replaced by neutral ammonium acetate varied in the present material markedly. The contents of all these cations tended to increase from sand soils to heavy clay soils, but in spite of the statistically significant differences found between the mean values of some textural classes, no reliable estimation of the content of exchangeable basic cations in an individual sample can be made on the basis of the soil texture alone.

Samples of virgin soils of the present material do not represent sampling places adjacent to those of cultivated lands. Therefore, it is not allowable to claim that differences between them would arise only from cultivation. In this material no statistically significant differences existed between the respective textural groups of virgin and cultivated soils in the mean contents of exchangeable $\mathrm{Mg}, \mathrm{K}$ and $\mathrm{Na}$, when expressed as me/100 $\mathrm{g}$ of soil or as a percentage of effective CEC. Because of the large variation, not even the mean content of exchangeable $\mathrm{Ca}$ as me/100 $\mathrm{g}$ was significantly lower in the virgin soils, but their higher acidity was characterized more distinctly by the lower average degree of saturation by $\mathrm{Ca}$. Even in this case the ranges were overlapping.

It was found in a previous paper (KAILA 1971) that the mean effective CEC was in the surface layers in our more or less acid clay soils about two thirds, in deeper layers of sandy soils about one third, and in all other groups about one half of the corresponding average potential CEC determined by neutral ammonium acetate. Therefore, the mean values reported in the present paper for the degree of saturation by the various exchangeable cations may be about 1.5 to 3 times as high as would be those calculated on the basis of the potential CEC.

Attention is ofter paid to the ratio of exchangeable cations, particularly to that of $\mathrm{Ca}$ to $\mathrm{Mg}$. According to Schmid (1965) their ideal ratio would be $5-8$ to 1 . In the present material, only in the plough layer of the sand and fine sand soils the mean ratio of $\mathrm{Ca}$ to $\mathrm{Mg}$ was somewhat higher than this, in the clay soils, and particularly in the heavy clay soils, it was even markedly lower. It seems that our acid soils of a finer texture are more in need of liming with ordinary limestone than with dolomitic limestone, as already suggested by KERÄNEN and JoKINEN (1964).

As far as the exchangeable $\mathrm{Mg}$ represent an estimation of plant available $\mathrm{Mg}$ in soil, the conditions in clay soils are, according to the present material, satisfactory with a minimum content of about $200-250 \mathrm{~kg} / \mathrm{ha}$ and a maximum of about $3000 \mathrm{~kg} / \mathrm{ha}$. In the plough layer of the coarser mineral soils the content of exchangeable $\mathrm{Mg}$ ranges from 30 to $1000 \mathrm{~kg} / \mathrm{ha}$, indicating that there are soils in which $\mathrm{Mg}$-deficiency may be expected. 


\section{REFERENCES}

Heinonen, R. 1956. Magnesiumin tarpeesta Suomen pelloissa. Summary: Magnesium requirement in Finnish agriculture. Agrogeol. Julk. No 65. Helsinki.

Karlı, A. 1971. Effective cation-exchange capacity in Finnish mineral soils. J. Sci. Agric. Soc. Finland 43:178-186.

KERÄNEN, T. \& JoKINEN, R. 1964. Magnesiumin puutteen torjuminen magnesiumpitoisuudeltaan erilaisilla kalkkikivijauheilla. Referat: Bekämpfung von Magnesiummangel mit Kalksteinmehlen verschiedenen Magnesiumgehaltes. Ann. Agr. Fenn. 3:244-255.

MarttilA, U. 1965. Exchangeable cations in Finnish soils. J. Sci. Agric. Soc. Finland 37:148-161.

MÄктTIE, O. \& VIRRI, K. 1965. On the exchange characteristics of some clay soils in the middle Uusimaa. Ann. Agr. Fenn. 4:277-289.

Scнмid, G. 1965. Einfluss der Basensättigung auf die Bodenfruchtbarkeit. Landw. Forsch. 28:97-107.

\section{SELOSTUS}

\section{SUOMEN KIVENNÄISMAIDEN EMÄKSISET VAIHTUVAT KATIONIT}

Armi KaIla

Yliopiston maanviljelyskemian laitos, Viikki

Neutraalilla ammoniumasetaatilla vaihdettavissa oleva $\mathrm{Ca}, \mathrm{Mg}, \mathrm{K}$ ja $\mathrm{Na}$ määritettiin 470 kivennäismaan näytteestä, jotka oli kerätty eri puolilta maata Lappia lukuunottamatta.

Vaihtuvien emäksisten kationien määrä kasvoi maan saveksen pitoisuuden mukana, mutta eri maalajien puitteissa vaihtelu oli niin suurta, että vaihtelurajat yleensä ylittivät toisensa.

Luonnontilaisten pintamaitten happamuus liittyi viljelymaita matalampaan Ca-kyllästysasteeseen; muiden kationien kohdalla ei vastaavissa maalajiryhmissä ollut merkitseviä eroja.

Syvempien kerrosten näytteissä oli eri maalajeissa yleensä keskimäärin vähemmän sekä vaihtuvaa Ca että K kuin muokkauskerroksen näytteissä. Sen sijaan $\mathrm{Mg}$ :n määrä oli hiekkamaita lukuunottamatta joko keskimäärin sama tai hiukan korkeampikin syvemmissä kerroksissa kuin muokkauskerroksessa.

Keskimääräinen Mg-kyllästysaste nousi muokkauskerroksen hiekka- ja hietamaiden $9 \%$ :sta aitosaven $30 \%$ :in. Pohjamaiden aitosavien ryhmässä se oli jopa $38 \pm 4 \%$.

Muokkauskerroksessa vaihtuvan Ca:n suhde $\mathrm{Mg}$ :iin oli hiekka- ja hietamaissa keskimäärin noin 9, hiue- ja hiesumaissa 6, karkeammissa savimaissa 4 ja aitosavissa vain 2 . 